\section{Half a mile of medicine}

\author{
John Launer
}

Every year I organise an Awayday for a group of young doctors from outside London on the subject of medical humanities. Its aim is to help them look at medicine through the perspective of history and the arts. It takes the form of a walking tour, visiting some of the major medical sites in the city. The doctors are all training to be general practitioners (GPs) in Kent, so they arrive in the capital at St Pancras station which is itself a great masterpiece of Victorian gothic architecture, even if it has no particular medical associations. The vicinity of the station is also rich with other significant buildings including the Crick Institute - Europe's biggest biomedical laboratory - and the British Library, which houses the largest collection of books and manuscripts in the world. However, the three destinations for the day are a little way further down the Euston Road: the Elizabeth Garrett Anderson Gallery, the Royal College of General Practitioners, and the Wellcome Collection. They are within a few minutes' walk of each other, and offer one of the most concentrated introductions to developments in modern medicine anywhere in the world.

The Elizabeth Garrett Anderson Gallery commemorates one of Britain's first women physicians (figure 1). It stands at the former site of the New Hospital for Women, which she founded so that working-class women could be treated by exclusively female doctors. Garrett Anderson was not the first woman to qualify as a doctor in the United Kingdom - Dr James Barry had done so earlier in the nineteenth century by presenting herself as a man - but she was the first who managed to exploit a loophole in the regulations and gain a licence to practise openly as a woman. Garrett Anderson first established the hospital at a dispensary near Marble Arch, moved it to bigger premises in 1874, and finally transferred it to the Euston Road in 1890 (figure 2). By that time, she had also gained a formal medical degree in France (having been denied one in England), won membership of the British Medical Association, seen Parliament pass an act allowing women

Associate Editor, Postgraduate Medical Journal, London, UK

Correspondence to Dr John Launer, London, UK; johnlauner@aol.com

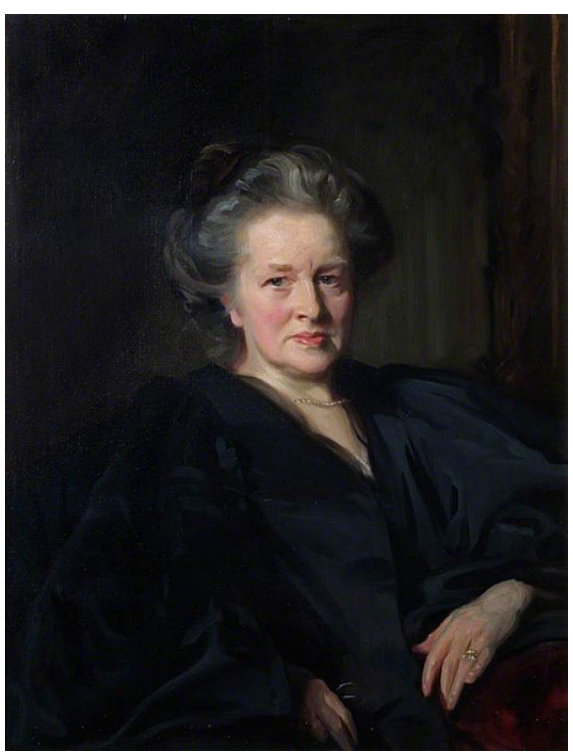

Figure 1 Elizabeth Garett Anderson: 1932. Reginald Grenville Eves after John Singer Sargent/BMA.

to qualify as doctors, co-founded the first medical school for women, and had three children. One of her daughters became a doctor and eminent campaigner for women's rights, as well becoming Elizabeth's biographer. ${ }^{1}$

\section{PLACES OF PILGRIMAGE}

The New Hospital was renamed after its founder following her death, and remained open until 2000, when its services were transferred to nearby University College Hospital. By that time, there were so many women doctors in Britain that it was no longer thought necessary to exclude men from the staff. After its closure, the building was due for demolition but was rescued by a vigorous

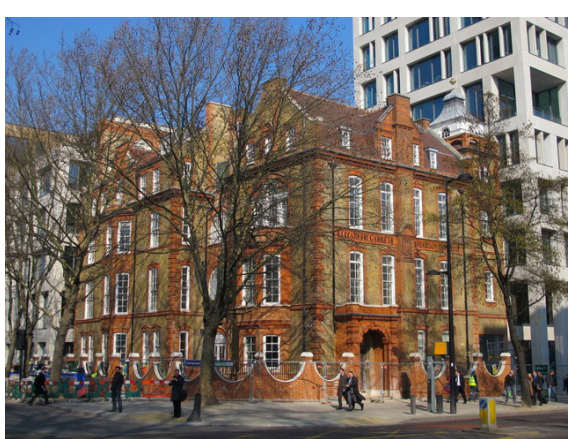

Figure 2 Elizabeth Garrett Anderson Hospital. campaign led by obstetrician Professor Wendy Savage. ${ }^{2}$ It now houses the trade union UNISON who have preserved part of the interior including its magnificent panelled entrance hall. The Elizabeth Garrett Anderson Gallery adjoins this (figure 3). It brings to life the stories of the woman and the hospital, in a display using video and sound recordings as well as written text, photographs, furniture, medical equipment and a range of other objects. It is a fitting place of pilgrimage for young doctors, both men and women, educating them about the endeavours of one of their predecessors in starting to achieve equity in the medical profession.

The short walk to our next destination on the Awayday also feels like a pilgrimage, especially for doctors who are embarking on a career in general practice. Some of them are surprised to discover that the Royal College of General Practitioners (RCGP) was only established in 1952, more than 400 years after the Royal College of Physicians of London, and 200 years later than the Royal College of Surgeons. (The respective Edinburgh colleges are even older.) The RCGP was almost the first academy of family doctors in the world - a token of how poorly the specialty was regarded by the wider medical profession until well into the twentieth century. Its work in the short time since then, along with its sister institutions elsewhere, has completely turned this around, so that family medicine now stands proudly alongside hospital specialities that were once seen as superior. The World Organisation of Family Doctors now has 118 member organisations representing half a million family doctors in over 130 countries, ${ }^{3}$ and the individual founders of these colleges and academies have cause for great pride just as the first women physicians did.

Like the Elizabeth Garrett Anderson Hospital, the RCGP was nomadic in its early years. ${ }^{4}$ It started out in a GP practice in Kensington, moving in 1968 to a nearby edifice of great history and beauty in Princes Gate. This attracted some criticism, since most of its members in London and the provinces had to work in rather less splendid premises. The choice of headquarters turned out to be even more unfortunate in 1980, when six members of a terrorist group barricaded themselves in the neighbouring building - the Iranian embassy - threatening to blow it up, along with themselves and 26 hostages. ${ }^{5}$ The College was evacuated and became the intelligence centre for members of the elite Special Air Services (SAS). They used this as the base for storming the embassy, leading to the 


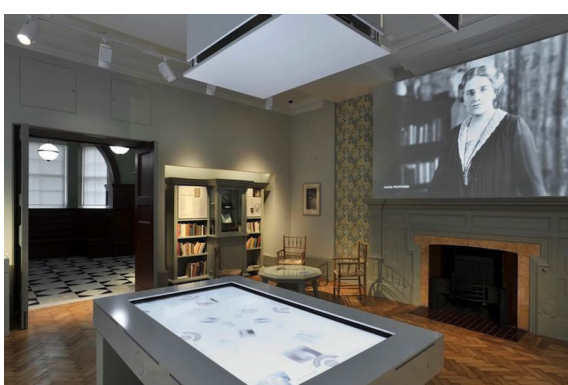

Figure 3 Elizabeth Garrett Anderson gallery.

deaths of all but one of the terrorists, and the rescue of all the hostages except for one who had already been murdered.

\section{FRIENDLY RECEPTION}

In time, it became clear that the RCGP building was unsuitable for a range of other reasons, and in 2012 it moved to its current location at 30 Euston Square: a listed building that started life early in the twentieth century as the offices of an assurance company (figure 4). The move has been widely celebrated, particularly since the interior is beautifully decorated with the original Royal Doulton tiles, and the place is altogether much less stuffy, more downto-earth, and very high-tech. It houses regular exhibitions, and is open to the public, so that its cafe has become a popular and lively meeting place (figure 5). When we visit, our group always receives a very friendly reception from one of the College's honorary officers, keen to encourage young doctors to become involved in its work of education and research.

Our third destination is just across the road. It is the Wellcome Collection. This is possibly the most important museum of medical artefacts in the world, and spectacular by any standards (figure 6). The museum is part of the Wellcome Trust, which has assets of over $£ 21$ billion, donating more to scientists and research centres than the British government does

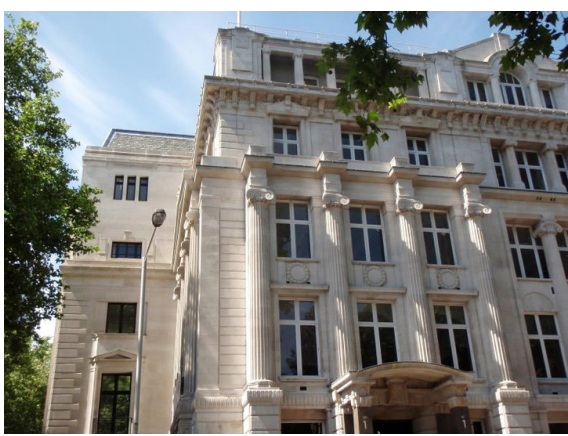

Figure 4 Royal College of General Practioners/RCGP.

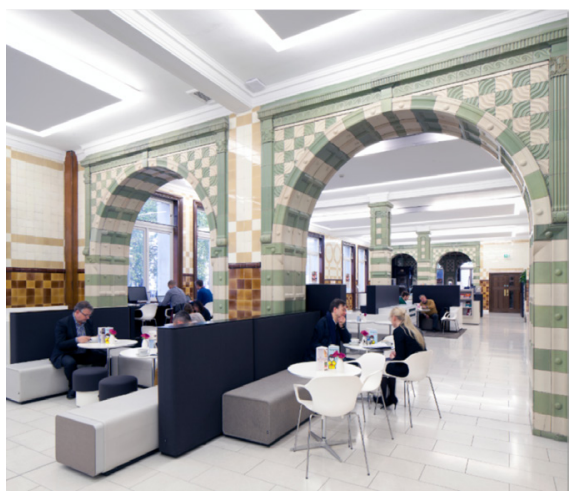

Figure 5 Royal College of General Practioners/RCGP.

through its Medical Research Council. Its funds derive largely from a bequest by its founder, Henry Wellcome, who made his fortune in the pharmaceutical industry, The museum was built to house the unprecedented collection of medical artefacts that Wellcome gathered over a 40 year career as an obsessive, rapacious and indeed ruthless collector and entrepreneur. In the past I have written in the Postgraduate Medical Journal about his complex biography and personality. ${ }^{6}$ This complexity is reflected in the way the collection is displayed, and the circumspect tone of its publicity. ${ }^{7}$

One of the benefits of bringing a group here is that we can examine and handle some of the exhibits in their luxurious reading room (figure 7 ). We have a chance to consider the incredible discoveries that created modern medicine, while also having to face the discomfort of hearing the dark side of its history. Nowadays, the curators make little attempt to disguise the ambiguous inheritance that the place represents, involving plunder and cruelty as well as preserving a huge range of artefacts that might otherwise have vanished, and showing that progress in medicine has also had its costs in human suffering.

If you are a Londoner or ever visit the capital, all these places will provide you

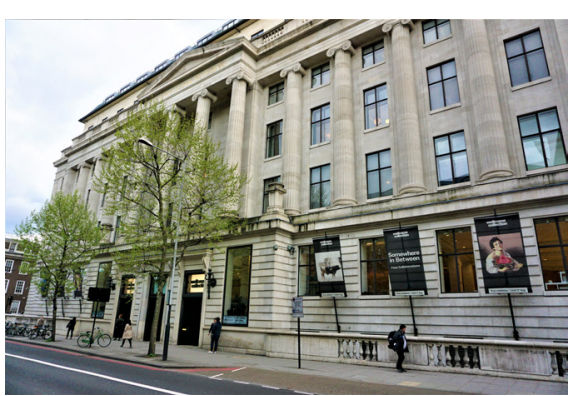

Figure 6 Wellcome Collection/Joy of Museums.

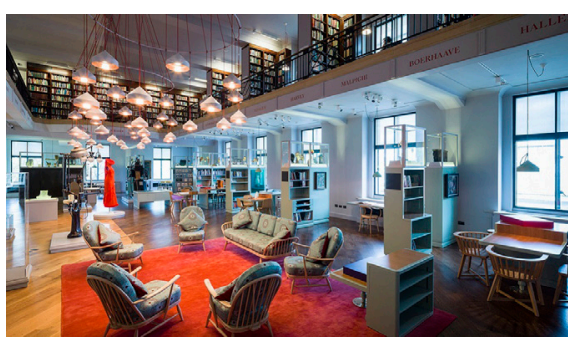

Figure 7 Wellcome Collection reading room.

with a fascinating window on medical history, as well as being close to many other significant national monuments where you can spend the rest of your day or week. If you do not get a chance to visit our city in the near future, you may still want to think about organising a similar tour of sites of medical interest nearer to home, introducing colleagues and trainees to some of their medical heritage, in all its richness and complexity.

Twitter John Launer @JohnLauner Contributors //

Funding The authors have not declared a specific grant for this research from any funding agency in the public, commercial or not-for-profit sectors.

\section{Competing interests None declared}

Patient consent for publication Not required.

Provenance and peer review Not commissioned; internally peer reviewed.

(C) Author(s) (or their employer(s)) 2020. No commercial re-use. See rights and permissions. Published by BMJ.

\section{(D) Check for updates}

To cite Launer J. Postgrad Med J 2020;96:239-240.

Postgrad Med J 2020;96:239-240.

doi:10.1136/postgradmedj-2020-137589

\section{REFERENCES}

1 Garrett Anderson L. Elizabeth Garrett Anderson 1836 1917. Cambridge: Cambridge University Press, 2015.

2 EGA for women. Available: https://www.egaforwomen. org.uk/index.html [Accessed 28 January 2020].

3 WONCA - World Organisation of Family Doctors. Available: https://www.who.int/workforcealliance/ members_partners/member_list/wonca/en/ [Accessed 28 January 2020].

4 Gray DP, Pereira Grey D. History of the Royal College of General Practitioners--the first 40 years. Br J Gen Pract 1992:42:29-35.

5 McAleese J. Leader of the SAS team that ended the 1980 siege of the Iranian embassy in London. Independent 30 August, 2011. Available: https://www. independent.co.uk/news/obituaries/john-mcaleeseleader-of-the-sas-team-that-ended-the-1980-siegeof-the-iranian-embassy-in-london-2345827.html [Accessed 28 January 2020]

6 Launer J. Henry Wellcome: the man who made medicine. Postgrad Med J 2017;93:507-8.

7 Wellcome Collection: who we are and what we do. Available: https://wellcomecollection.cdn.prismic.io/ wellcomecollection\%2F4207b8c8-70d1-461e-bea6f9da13f9a55a_wellcome+collection+who+we+are+ and+what+we+do_2.pdf [Accessed 28 January 2020]. 